\title{
Phytosociometry, a new vision, for evaluating the potential of steppe rangelands and the sustainability of extensive sheep farming systems
}

\author{
Hadj Bouyahia ${ }^{a,{ }^{*}}$, Kheloufi Benabdeli a, Mohammed Mahammadi ${ }^{b}$, Mohammed Toufik Youcefi ${ }^{b}$ \\ a Geo-Environment and Spatial Development Laboratory, University of Mascara, Algeria \\ b Centre Universitaire Salhi Ahmed de Naâma, Algeria \\ * Corresponding author: h.bouy@yahoo.fr
}

\section{Article history}

Received 25 July 2018

Revised 12 September 2018

Accepted 4 October 2019

Published Online 25 August 2019

\begin{abstract}
Some plant species are frequently found together under edaphic-climatic conditions, so similarity of presence and association becomes an indicator of ecosystem conditions. The idea of evaluation of the quality of rangelands by breeders in the steppe zone is quite different from those applied by academic methods, so the mentions "good, average, and poor" find a particular meaning for breeders, especially farmers, nomads, and transhumant. Surveys conducted on the sustainability of livestock systems in the steppe zone of Naâma have led to the importance of the Pole resources, especially pasture management. A high biomass does not necessarily mean a good pasture course, especially when toxic plants present, which hinder the exploitation of the rangeland. The knowledge of the plants, their stages of evolution, and their distribution, are indices of orientation for the use of the course and the duration of exploitation, of course among the connoisseur breeders. So, a new approach of course evaluation becomes a necessity to give an explanation to the reasoning of the direct operator who is the breeder. With this in mind, we proposed the phytosociometry method, based on the link between BioMarker and other annexations, a new method to determine the nature of phyto-association at the spatial scale in an arid environment, which can correct the vision of evaluation and estimation of the forage potential of a steppe rangeland.
\end{abstract}

Keywords: Phytosociometry, phyto-association, biomarker, steppe, sustainability

() 2019 Penerbit UTM Press. All rights reserved

\section{INTRODUCTION}

The intensification of agricultural activity in the steppe areas is one of the suspected causes of rangelands degradation. The majority of the studies addressing other factors that may contribute to the phenomenon, including climatic order (e.g. drought) and agricultural management (e.g. overgrazing).

The arid steppes are structured and named based on perennial plants in individual clumps (Montana, 1992). According to the presence and dominance of perennial species, the Esparto steppe (Lygeum spartum L.) and Alfa steppe (Stipa tenacissima) are documented in most books on the subject. The Esparto steppes usually occupy a dynamic stage intermediate between the Alfa steppes and the bush steppes. The calculation of the recovery of the first dominant species shows that Esparto grass is the species with the highest recovery in the area of Naâma (Bouchetata et al., 2005). Its great ecological plasticity and germination power ensure that this plant is able to form extension of spaces in semi-arid and arid zone (Aidoud, 1989). Unlike the Alfa grass, studies have been done regarding the ecological characteristics of the Esparto grass and its role in maintaining the equilibrium of the steppe ecosystem (Houérou, 1995).

In this work, the authors were interested in the question whether it is possible that the presence and dominance of the perennial species may affect the other species that are in association. In addition, it is possible that there are other forms of natural degradation that represses the presence of the species, despite its ecological wealth.

\section{EXPERIMENTAL}

\section{Presentation of the study area}

Naâma Province (Wilaya de Naâma), which is part of the southern high plains of Oran, occupies an area of about 3 million hectares and it stretches between $32^{\circ} 08^{\prime} 45^{\circ}$ and $34^{\circ} 22^{\prime} 13$ "north latitude and $0^{\circ}$ $36^{\prime} 45^{\prime \prime}$ at $0^{\circ} 36^{\prime} 45$ "west longitude. It has been reported that Esparto range covers about $5 \%$ of the area. This study was conducted at the station of Oum el-Djem, North West of Naâma (Fig. 1) on a protected area of 50 hectares with original vegetation of Esparto grass (Lygeum spartum $\mathrm{L}$ ).

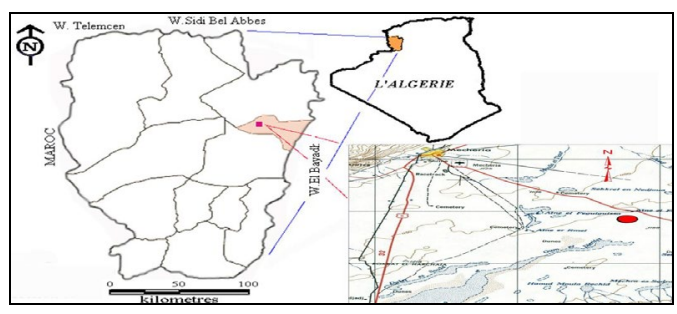

Fig. 1 Location of the Oum el-Djem study area 


\section{Methodology}

This study referred the dominant perennial species, Esparto plant (Lygeum spartum L.) as the bio-marker. The objective of this study was to determine the influence of the Bio-marker on the distribution of the species, which form there the phytosociological procession, as well as their number, abundance, and/or dominance of these steppic species with the peripheral of the bio-marker, an index that informs about the possible relationships between the master plant and annexations, whether symbiotic, protective, or competitive.

Phytosociometry relies on taking the master plant as a benchmark and determining the metric distribution of the species present and their number around this marker at distances of $20 \mathrm{~cm}$ for four concentric circles with radii of $20,40,60$, and $80 \mathrm{~cm}$, forming strips of $20 \mathrm{~cm}$ around the diameter of the bio-marker (Fig. 2)

To create an inventory of the maximum number of species, we proceeded to do a continuous count with additional species, which spreads between the beginning of March and April. The shape of the survey was adapted to the circular shape of the bunch, where the rays were made from the axis of the bunch concerned. 30 units of tufts were taken at random with recording of the height and diameter of the bio-mark as additional indices.

Green (1979) considers that the smallest units are generally the best because the precision of the estimation is usually improved when the organisms are aggregated. In addition, these small units allow the creation of large samples that have the effect of blurring the bias of some estimators.

The order of magnitude of the inventory area depends on the type of stand. The surface of the statement must meet both criteria, namely:

i. Be sufficient for the notation of all the species constituting the floristic procession.

ii. Be optimal to avoid any confusion between two juxtaposed tufts.

For this purpose, some measurements were made on five randomly selected parcel samples $\left(100 \mathrm{~m}^{2}\right)$ to release the easement or average living space per tuft of the Esparto (Table 1).

Table 1 Sampling area.

\begin{tabular}{|c|c|c|c|c|c|}
\hline $\mathrm{N} \mathrm{S}$ & Coordinate & s & $\mathbf{N}$ & $L s=S / N$ & $\begin{array}{c}\text { Equivalent } \\
\text { circle } \\
\text { diameter }\end{array}$ \\
\hline & $\begin{array}{l}X: 0767676 \\
Y: 3703475\end{array}$ & 100 & 18 & 5.56 & 2.66 \\
\hline 2 & $\begin{array}{l}X: 0767248 \\
Y: 3703179\end{array}$ & 100 & 35 & 2.86 & 1.91 \\
\hline 3 & $\begin{array}{l}X: 0767683 \\
Y: 3702214\end{array}$ & 100 & 22 & 4.55 & 2.41 \\
\hline 4 & $\begin{array}{l}X: 0769685 \\
Y: 3701613\end{array}$ & 100 & 43 & 2.33 & 1.72 \\
\hline 5 & $\begin{array}{l}X: 0767767 \\
Y: 3703517\end{array}$ & 100 & 29 & 3.45 & 2.10 \\
\hline & Sum & 500 & 147 & 3.40 & 2.08 \\
\hline
\end{tabular}

Ns:Number of samples, N: Number of Esparto Tufts, $\mathbf{S}:$ Area $\left(\mathrm{m}^{2}\right)$, L s: Living space per Tufts $\left(\mathrm{m}^{2}\right)$

Based on the diameters recorded in Table 1, the average diameter of the readings was approximately $2 \mathrm{~m}$, which was between the axis of the biomarker to the limit of the last circle.

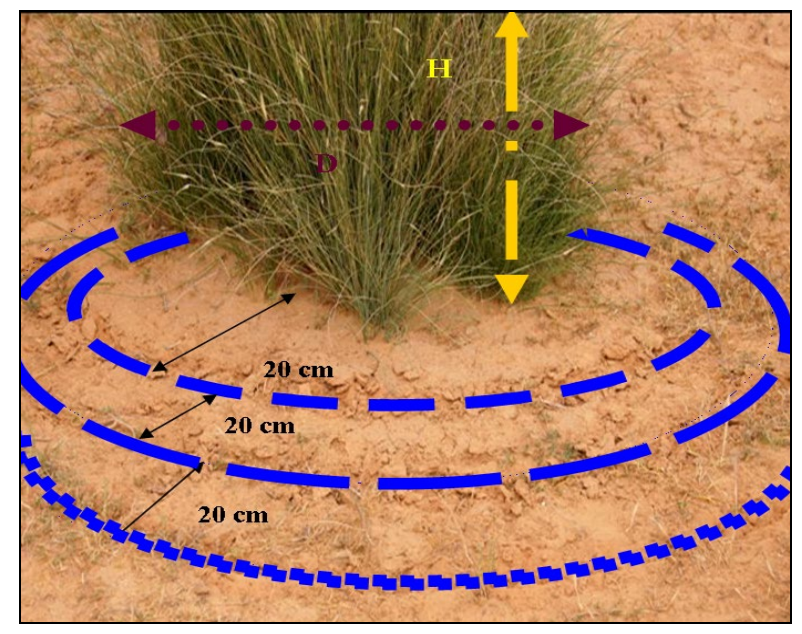

Fig. 2 Measurements of the bio-marker, Esparto plant (Lygeum spartum L.)

\section{RESULTS AND DISCUSSION}

\section{The closest and furthest species in diameter of the esparto grass}

The result showed that with species distribution as a function of distance from the bio-marker, the closest species $(2 \mathrm{~cm})$ of the perimeter of the Esparto was Karkaz (Diplotaxis virgata) while the farthest $(79 \mathrm{~cm}$ ) was Guiz (Scorzonera undulata) (Table 2). About 17 species mark a presence near the device of the bio-marker in the first band of $20 \mathrm{~cm}$, while 2 species mark a distant presence in the fourth band between the circle of 60 and the circle of $80 \mathrm{~cm}$.

In this study, the researchers receive assistance from the local breeders in determining the vernacular names of the plants. Based on their prior knowledge in botany, they claimed that Guiz plant (Scorzonera undulata) is never found at the foot of the Esparto, since they collect these sweet and fatty roots for consumption and traditional therapeutic use. Moreover, they also stated that the progression and evolution of the bio-marker's clover bud represses the presence of Cherira plant (Salsola vermiculata).

Table 2 The distance measurements of species around the bio-marker, Esparto plant (Lygeum spartum L.)

\begin{tabular}{|c|c|c|c|c|}
\hline $\begin{array}{l}\text { Vernacular } \\
\text { Name }\end{array}$ & $\begin{array}{c}N \\
(\mathrm{~cm})\end{array}$ & $D(\mathrm{~cm})$ & $\begin{array}{c}\mathrm{N}+\mathrm{D} \\
12 \\
(\mathrm{~cm})\end{array}$ & Scientific Name \\
\hline $\begin{array}{l}\text { Souifia } \\
\text { Nefl } \\
\text { Khafour } \\
\text { Karata }\end{array}$ & $\begin{array}{l}5.30 \\
6.93 \\
6.48 \\
11.33\end{array}$ & $\begin{array}{l}56.70 \\
57.40 \\
55.93 \\
54.11\end{array}$ & $\begin{array}{l}31.00 \\
32.17 \\
31.20 \\
32.72\end{array}$ & $\begin{array}{l}\text { Micropus bombycinus } \\
\text { Trigonella anguina } \\
\text { Hordeum murinum } \\
\text { Romulea bulbocodium }\end{array}$ \\
\hline Mekharssa & 15.24 & 56.31 & 35.78 & Astragalus tenuifolius \\
\hline $\begin{array}{l}\text { Zentit } \\
\text { lekhrouf }\end{array}$ & 21.71 & 50.75 & 36.23 & Schismus barbatus L. \\
\hline $\begin{array}{l}\text { Fatet lehdjar } \\
\text { Tmar leghrab } \\
\text { Ghodame }\end{array}$ & $\begin{array}{l}15.50 \\
28.00 \\
20.83\end{array}$ & $\begin{array}{l}50.50 \\
48.44 \\
48.04\end{array}$ & $\begin{array}{l}33.00 \\
38.22 \\
34.44\end{array}$ & $\begin{array}{l}\text { Herniaria fontanesii B. } \\
\text { Echium pycnanthum } \\
\text { Frankenia thymifolia }\end{array}$ \\
\hline Guessis & 13.00 & 56.40 & 34.70 & $\begin{array}{l}\text { Helianthemum } \\
\text { ledifolium }\end{array}$ \\
\hline Raguem & 16.91 & 44.36 & 30.64 & Erodium garamantum \\
\hline $\begin{array}{l}\text { Cheham } \\
\text { Lâaoud }\end{array}$ & 15.95 & 41.45 & 28.70 & Launaea capitata \\
\hline Tif mâalam & 22.35 & 41.85 & 32.10 & Salvia verbenaca \\
\hline Larbiane & 13.43 & 56.29 & 34.86 & $\begin{array}{l}\text { Anacyclus } \\
\text { cyrtolepidioides }\end{array}$ \\
\hline \multirow{2}{*}{$\begin{array}{l}\text { Moulbina } \\
\text { Jerjir }\end{array}$} & 23.82 & 42.91 & 33.36 & Launaea arborescens \\
\hline & 18.27 & 36.07 & 27.17 & $\begin{array}{l}\text { Sisymbrium } \\
\text { runcinatum }\end{array}$ \\
\hline Kherchouf & 31.00 & 56.00 & 43.50 & Onopordon acaule \\
\hline Redjel Hadjla & 28.88 & 48.63 & 38.75 & Salsola cyclophylla \\
\hline Sir Leghzal & 25.00 & 54.71 & 39.86 & Salsola tragus \\
\hline Lalma & 35.40 & 47.60 & 41.50 & Plantago albicans \\
\hline Zaouai & 29.58 & 40.33 & 34.96 & Stipa parviflora \\
\hline
\end{tabular}




\begin{tabular}{|c|c|c|c|c|}
\hline Adjram & 22.25 & 46.33 & 34.29 & Anabasis articulata \\
\hline Mechawka & 27.67 & 41.42 & 34.54 & Silybum marianum \\
\hline $\begin{array}{l}\text { Djayaf } \\
\text { Lebeari }\end{array}$ & 13.00 & 79.00 & 46.00 & Cutandia divaricata \\
\hline Nâamia & 34.00 & 43.50 & 38.75 & Malva aegyptiaca \\
\hline Sengha & 33.08 & 42.42 & 37.75 & Lygeum spartum \\
\hline Reguig & 36.50 & 53.00 & 44.75 & Helianthemum lippii \\
\hline Guetfa & 33.55 & 39.82 & 36.68 & Atriplex halimus \\
\hline Methnan & 28.43 & 40.86 & 34.64 & Thymelaea hirsuta \\
\hline Rik leghzal & 9.00 & 24.00 & 16.50 & Salsola sp. \\
\hline Odid & 18.33 & 43.00 & 30.67 & Launaea mucronata \\
\hline Zafzaf & 41.00 & 56.00 & 48.50 & Hellianthemum hirtum \\
\hline Karkaz & 2.00 & 52.00 & 27.00 & Diplotaxis virgata \\
\hline Harmal & 37.50 & 64.50 & 51.00 & Peganum harmala \\
\hline Ziouane & 30.00 & 56.00 & 43.00 & Lolium perenne L. \\
\hline $\begin{array}{l}\text { Messwak } \\
\text { Râyene }\end{array}$ & 18.00 & 30.00 & 24.00 & $\begin{array}{l}\text { Ceratocephalus } \\
\text { falcatus }\end{array}$ \\
\hline Sir Lemâaza & 25.00 & 50.00 & 37.50 & Iris sisyrinchium \\
\hline Cherira & \multicolumn{2}{|c|}{70.00} & 70.00 & Salsola vermiculata I. \\
\hline Guiz & \multicolumn{2}{|c|}{76.00} & 76.00 & Scorzonera undulata \\
\hline Serr & \multicolumn{2}{|c|}{10.00} & 10.00 & Atractylis serratoiides \\
\hline Zaâzaâ & \multicolumn{2}{|c|}{30.00} & 30.00 & $\begin{array}{l}\text { Coronilla juncea } \\
\text { Pomeli }\end{array}$ \\
\hline
\end{tabular}

$\mathrm{N}$ : The Nearest, D: the most Distant, N+D /2: Average Distance

\section{Metric distribution of species around the Biomarker}

The illustration by radar graph (Fig. 3) gives another clarification on the phenomenon of distribution and repartition of species around the bio-marker. Between the nearest and the farthest presence of the species around the bio-marker, we noticed that the range of distribution of each species was affected by the bio-marker. Therefore, we can deduce that the mass presence has a direct influence on the mosaic present in the appendix.

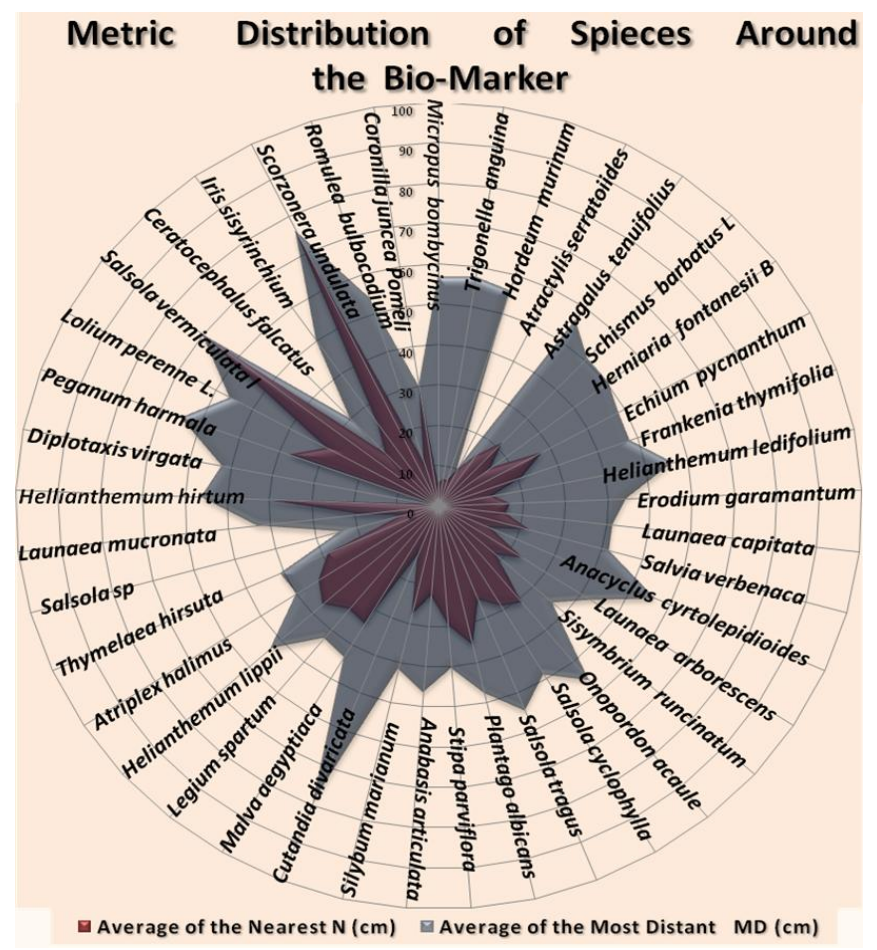

Fig. 3 Metric distribution of species around the bio-marker, Esparto plant (Lygeum spartum L.)
Importance and number of appearance of the subjects in the bands

Fig. 4 presents the recording the number of appearance of the species around the bio-marker.

First group with 4 appearances encompassing 23 species. There were six very abundant species of a very large number: Schismus barbatus L. 672 individuals; Astragalus tenuifolius 857 individuals; Romulea bulbocodium 861 individuals; Hordeum murinum 1593 individuals; Trigonella anguina 1593 individuals; and Micropus bombycinus 2123 individuals. Next, the remaining 17 species had from 9 to 170 individuals: Launaea mucronata, Thymelaea hirsute, Malva aegyptiaca, Cutandia divaricata, Silybum marianum, Anabasis articulate, Stipa parviflora, Plantago albicans, Salsola tragus, Onopordon acaule, Sisymbrium runcinatum, Launaea arborescens, Anacyclus cyrtolepidioides, Salvia verbenaca, Launaea capitata, Erodium garamantum, and Frankenia thymifolia.

- Second group with 3 appearances including 09 species from 4 to 267 individuals: Peganum harmala, Diplotaxis virgata, Helianthemum lippii, Lygeum spartum, Atriplex halimus, Salsola cyclophylla, Helianthemum ledifolium, Echium pycnanthum, and Herniaria fontanesii $\mathrm{B}$.

- Third group with 2 appearances including 04 species with a minimal number of 2 to 10 individuals: Iris sisyrinchium, Ceratocephalus falcatus, Lolium perenne L., and Salsola sp.

- Fourth group with 1 appearance including 05 species of a minimal number of 1 to 6 individuals: Coronilla juncea Pomeli, Atractylis serratoiides, Scorzonera undulata, Salvia verbenaca, and Hellianthemum hirtum.

It is worth mentioning that when we talk about the number of appearances that species are inventoried on 120 bands, since we have 30 tufts and for each 4 bands of $20 \mathrm{~cm} \mathrm{so:} 30 * 4=120$ bands, so the species that were present by 4 appearances means that they were found in a total of 120 bands, those of a single appearance were found only in a band on 120 bands, 1/120.

The fourth group that includes the species Coronilla juncea Pomeli, Atractylis serratoiides, Scorzonera undulata, Salvia verbenaca, and Hellianthemum hirtum means that these species are very rare in the course. Thus, one can deduce the richness or poverty of a pasture according to the presence of highly palatable species. Meanwhile, the quality of grazing depends greatly on the species consumed by the herds.

\section{Metric distribution of the family at the turn of the biomarker}

When combining species with family, we found that the distributions around the bio-marker differ in distance for the 18 families (Fig. 5):

1- Very close to the bio-marker, which is actually a Poaceae, There were 02 families: Ranunculaceae and Brassicaceae, $24 \mathrm{~cm}$ and $27 \mathrm{~cm}$, respectively, in average.

2- Moderately close to the bio-marker, we found 13 families: Geraniaceae, Lamiaceae, Fabaceae, Caryophyllaceae, Frankeniaceae, Thymelaeaceae, Iridaceae, Asteraceae, Chenopodiaceae, Poaceae, Boraginaceae, Malvaceae and Amaranthaceae.

3- Far from the bio-marker, there were 02 families, Plantaginaceae and Citaceae. 4- Very far from the bio-marker was the Nitrariaceae family. 

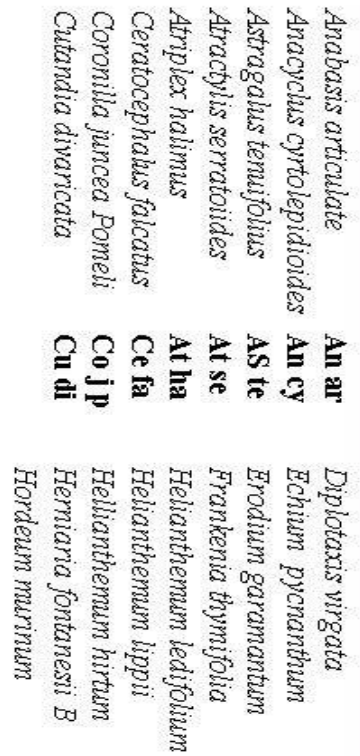

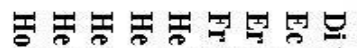
1.:

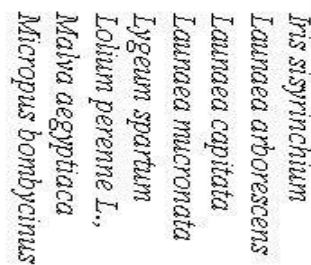

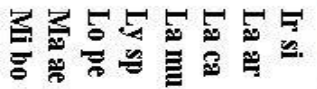

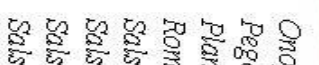
क

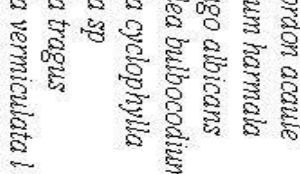

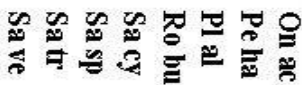

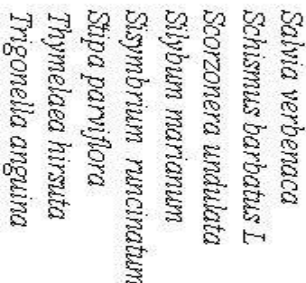

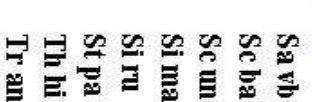

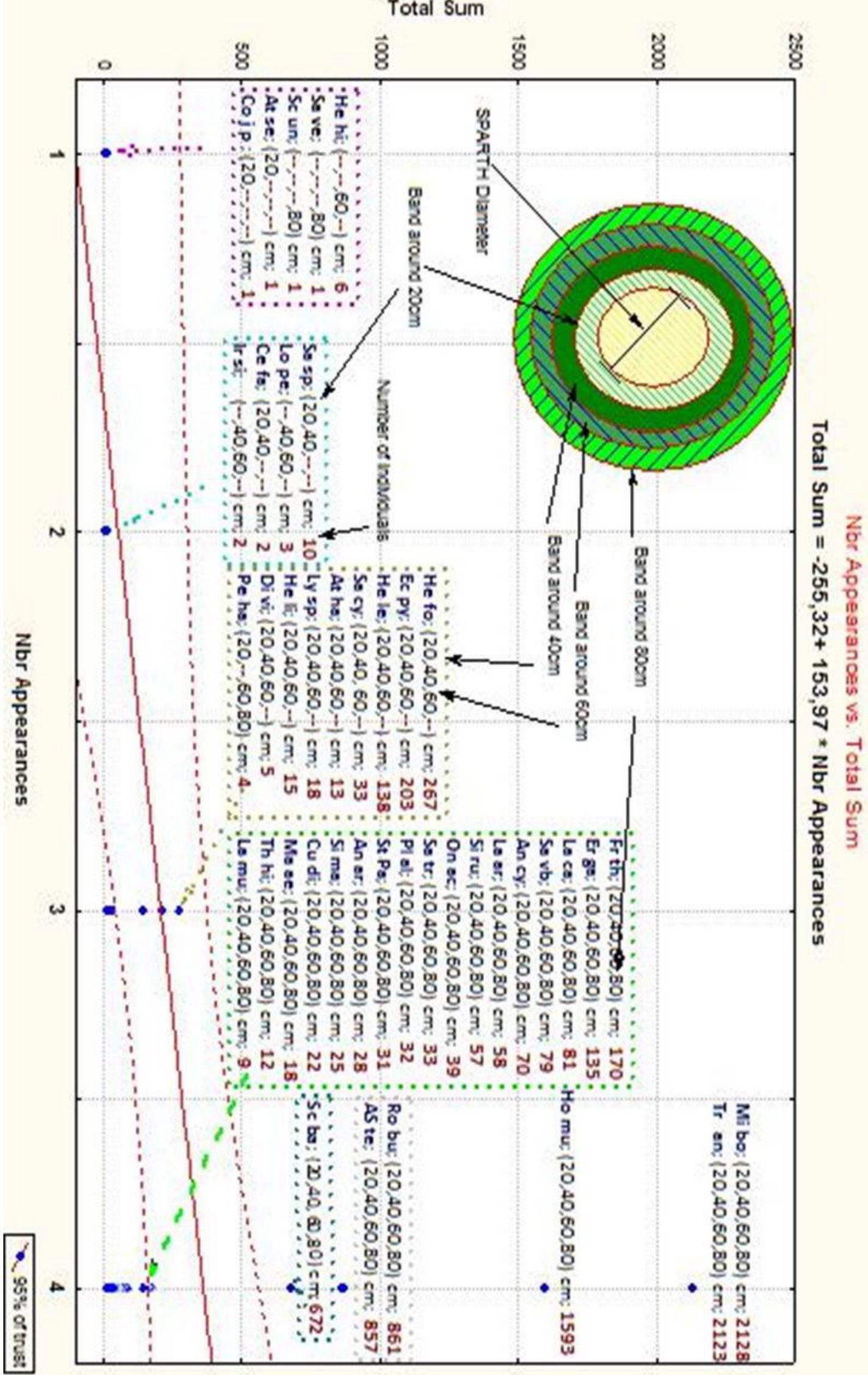

Total Sum

Fig. 4 Number of appearances and importance of the species around the bio-marker, Esparto plant (Lygeum spartum L.) 


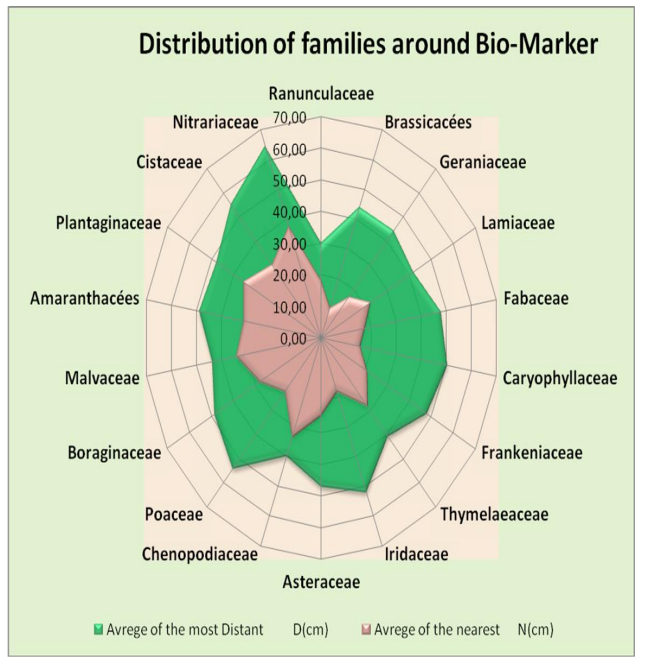

Fig. 5 Distribution of families around the bio-marker, Esparto plant (Lygeum spartum L.)

\section{Effect of Esparto parameter on the presence and importance of species \\ Species}

It appears that the height and diameter parameters of the Esparto clump can influence the number of species in the vicinity of the esparto grass (Table 2). The results obtained show that the height of the esparto tree limits the number of species. For instance, when the height of the esparto clump exceeded $75 \mathrm{~cm}$, only 28 species were record, while when the tufts were less than $70 \mathrm{~cm}$ high, there were 40 species recorded. If the height was below $70 \mathrm{~cm}$, the diameter of the Esparto's tufts cannot be measured due to the formation of regeneration seeds.

Table 2 Number of species according to height and diameter of the Esparto plant (Lygeum spartum L.).

\begin{tabular}{|c|c|c|c|c|}
\hline $\begin{array}{c}\text { Diameter/Height } \\
\text { (cm) }\end{array}$ & $\mathbf{1 2 0 - 1 0 0}$ & $\mathbf{9 0 - 7 5}$ & $\mathbf{7 0 - 5 0}$ & Total \\
\hline $110-90$ & 26 & 19 & 0 & $\mathbf{2 8}$ \\
\hline $85-75$ & 26 & 22 & 0 & $\mathbf{2 8}$ \\
\hline $70-60$ & 28 & 31 & 30 & $\mathbf{4 0}$ \\
\hline Total & $\mathbf{3 1}$ & $\mathbf{3 3}$ & $\mathbf{3 0}$ & $\mathbf{4 1}$ \\
\hline
\end{tabular}

Next, it is concluded that the number of individuals are affected by the height and diameter of the bio-marker (Table 3). For example, when the height of the esparto clump exceeded $75 \mathrm{~cm}, 6561$ individuals were record, while when the tufts were more than $90 \mathrm{~cm}$ high, the number regressed to 2307 .

Table 3 Number of individuals according to height and diameter of the Esparto plant (Lygeum spartum L.)

\begin{tabular}{|c|c|c|c|c|}
\hline $\begin{array}{c}\text { Diameter/Height } \\
(\mathbf{c m})\end{array}$ & $\mathbf{1 2 0 - 1 0 0}$ & $\mathbf{9 0 - 7 5}$ & $\mathbf{7 0 - 5 0}$ & Total \\
\hline $110-90$ & 1128 & 1179 & 0 & $\mathbf{2 3 0 7}$ \\
\hline $85-75$ & 2582 & 2895 & 0 & $\mathbf{5 4 7 7}$ \\
\hline $70-60$ & 806 & 2093 & 3662 & $\mathbf{6 5 6 1}$ \\
\hline Total & $\mathbf{4 5 1 6}$ & $\mathbf{6 1 6 7}$ & $\mathbf{3 6 6 2}$ & $\mathbf{1 4 3 4 5}$ \\
\hline
\end{tabular}

\section{Correlation between, bio-marker factors and number of individuals of the related species}

For further confirmation on the effect of the height and diameter of the bio-marker on the number of individuals and scattered species around it, calls for a correlation ex amen. As shown in Table 4, it is apparent that there is a negative correlation between number of individuals and esparto height of -0.47 (Table 4).

Table 4 Correlation between height and diameter factors on the number of individuals.

\begin{tabular}{|l|c|c|c|}
\hline & Height & Diameter & Indivduals \\
\hline Height & 1 & 0 & -0.47 \\
\hline Diameter & 0.00 & 1 & 0.10 \\
\hline Individuals & -0.47 & 0.10 & 1 \\
\hline
\end{tabular}

\section{CONCLUSION}

By taking the dominant perennial species as a biomarker, we can see that the distribution of species in a Esparto steppe is not random. There is a relationship between the dominant perennial species with the vegetation around it which is either forming "symbiosis, competition, or protection". In the same way, the nutritional nature, mineral requirement, and water condition of each species in this distribution are marked by the competition between the perennial and annual species.

In the field study, on a protected route, there were 41 species including the Esparto plant (Lygeum spartum L.) and 14345 individuals distributed in 120 bands around the 30 tufts of esparto, with 4 bands for each tuft. The number of species and individuals decrease in a remarkable way depending on the distance between the perimeter of the bio-reference and the circle of delimitation. Since the number in the bands of $20 \mathrm{~cm}$ was very high compared to those of 80 $\mathrm{cm}$, this result reinforced the hypothesis that the distribution depends to the nature of regeneration of the species, that is by grains or rhizomes, the number of individuals for each species is according to the faculty of production of the grains and germination, except that the thrust of the plants does not installs only at distances conditioned by the nature of the needs and volume of the plant takes master in the course.

As a result, it is noted that the above-ground biomass of the Esparto grass, its height and diameter directly influences the number of species and individuals around it, suggesting that the evolution of clumps of esparto grass beyond well-defined norms become a cause of regression of diversity and the importance of appendix species, a form of natural degradation following a competition between perennial plant that takes space by volume and not by number.

Currently, there is no direct exploitation of Esparto as before where it was used for handicrafts such as ropes, brooms, carpets, baskets. It is noteworthy that a phenomenon that promotes the expansion of tufts will affect the training phyto-sociological. Therefore, it is necessary to monitor the parameters of evolution of the esparto when using the protected routes.

\section{ACKNOWLEDGEMENT}

The authors wish to acknowledge: Forests conservation of Naâma (Algeria) and the breeders of the Naâma region for their contributions on the ground.

\section{REFERENCES}

Aidoud, A .1989. Contribution to the study of steppe ecosystems, grazed by the high plains Alger-Oranaises (Algeria): Function and evaluation of plant resources. Doct. On state. Sci. USTHB. Alger; 1989.. 240p.

Bouchetata, T. B., Bouchetata, A. A. .2005. Dégradation des écosystèmes steppiques et stratégie de développement durable. Mise au point méthodologique appliquée à la Wilaya de Nâama (Algérie), Développement durable et territoires [En ligne], Varia (2004-2010), mis en ligne le 02 septembre 2005, consulté le 30 avril 2018. URL: http://developpementdurable.revues.org/1339; DOI: 10.4000/ développement durable.1339

Green, A.A.1979. Développement des parcs nationaux. La végétation du Parc national de la Pendjari et des régions avoisinantes.PNUD/FAO BEN/77/011 document du travail 8, Cotonou, Bénin, 87p.

Le Houérou HN. 1995. Bioclimatology and biogeography of the arid steppe of northern Africa. Biological diversity, sustainable development and desertification, Mediterranean options, Sér, B: Research and studies, pp: 1396.

Montana C 1992. The colonization of bare areas in two-phase mosaics of an arid ecosystem. J. Ecol. 80: 315-327. 